\title{
ANNUAL VOLUME CONTENTS
}

Volume 65, Numbers 1-4, February-November 2006

Published by the Association for Asian Studies, Inc.

Through Volume XV, The Journal of Asian Studies was known as The Far Eastern Quarterly, and the Association was known as the Far Eastern Association, Inc.

Editorial Foreword

$1,249,459,667$

\section{Articles}

Teresa A. Algoso, "Thoughts on Hermaphroditism: Miyatake Gaikotsu and the

Convergence of the Sexes in Taishō Japan"

Barbara Andaya, "Presidential Address - Oceans Unbounded: Transversing Asia across 'Area Studies"”

Yoshiko Ashiw A and David L. WANK, "State, Association, and Religion in Southeast China: The Politics of a Reviving Buddhist Temple"

Rebecca M. Brown, "Inscribing Colonial Monumentality: A Case Study of the 1763

Patna Massacre Memorial"

Uradyn E. Bulag, “The Yearning for 'Friendship': Revisiting 'The Political' in

Minority Revolutionary History in China"

Robert Culp, "Rethinking Governmentality: Training, Cultivation, and Cultural Citizenship in Nationalist China"

Christian de Pee, "Till Death Do Us Unite: Texts, Tombs, and the Cultural History of Weddings in Middle-Period China (Eighth through Fourteenth Centuries)"

Michael Dylan Foster, "Strange Games and Enchanted Science: The Mystery of Kokkuri

Vincent Goossaert, "1898: The Beginning of the End for Chinese Religion?”

Michael Hutt, "Things That Should Not Be Said: Censorship and Self-Censorship in the Nepali Press Media, 2001-2"

David N. Lorenzen, "Marco della Tomba and the Brahmin from Banaras:

Missionaries, Orientalists and Indian Scholars"

Ethan Mark, “'Asia's' Transwar Lineage: Nationalism, Marxism, and 'Greater Asia' in an Indonesian Inflection"

David Mosse, "Rule and Representation: Transformations in the Governance of the

Water Commons in British South India"

Ping Shao, "Huineng, Subhuti, and Monkey's Religion in Xiyou ji"

SRIRUPA RoY, “'A Symbol of Freedom': The Indian Flag and the Transformations of Nationalism, 1906-2002”

Yasmin SAikia, "Religion, Nostalgia and Memory: Making an Ancient and Recent

Tai-Ahom Identity in Assam and Thailand"

Michiko Suzuki, "Writing Same-Sex Love: Sexology and Literary Representation in Yoshiya Nobuko's Early Fiction"

Wei Hua, "How Dangerous Can the Peony Be? Textual Space, Caizi Mudan ting, and Naturalizing the Erotic"

Ellen Widmer, "Foreign Travel through A Woman’s Eyes: Shan Shili’s Guimao luxing $j i$ in Local Perspective"

Tomiko Yoda, "First-person Narration and Citizen-Subject: The Modernity of Ogai's

'The Dancing Girl'” 


\section{Book Reviews}

Asia: Comparative and Transnational

BAO, Marital Acts: Gender, Sexuality, and Identity among the Chinese Thai Diaspora

\{Alan Klima\}

Berger, The Battle for Asia: From Decolonization to Globalization \{Sumner J. LA

Croix

Brook, Collaboration: Japanese Agents and Local Elites in Wartime China \{SUSAN

GLOSSER\}

148

CAllahan, Contingent States: Greater China and Transnational Relations \{LOW ELL

DitTMER

Chen, As Borders Bend: Transnational Spaces on the Pacific Rim (W ILliam A.

Callahan\}

De BARY, Nobility and Civility: Asian Ideals of Leadership and the Common Good \{THOMAS

KEIRSTEAD\}

601

Geithner, Johnson and Chen (eds.), Diaspora Philanthropy and Equitable Development

in China and India \{CARLA P. FreEmAN\}

Guo, Asia's Educational Edge: Current Achievements in Japan, Korea, Taiwan, China, and

India $\{$ MARK LINCICOME

Herzstein, Henry R. Luce, Time, and The American Crusade in Asia \{Simei Qing\}

Inoguchi, Basáñez, TAnaka, and Dadabaev (eds.), Values and Life Styles in

Urban Asia: A Cross-Cultural Analysis and Sourcebook Based on the AsiaBarometer Survey

of 2003 \{XiANGMING CHEN\}

Kelley, Beyond the Bronze Pillars: Envoy Poetry and the Sino-Vietnamese Relationship \{LI

TANA\}

Knechtes and Vance (eds.), Rhetoric and Discourses of Power in Court Culture:

China, Europe, and Japan \{Thomas LamarRe\}

Lincoln, East Asian Economic Regionalism \{Sumner J. LA Croix\}

\section{China}

A Tw ILL, The Chinese Sultanate: Islam, Ethnicity, and the Panthay Rebellion in Southwest China, 1856-1873 \{C. Patterson Giersch\}

Ben-Dor Benite, The Dao of Muhammad: A Cultural History of Muslims in Late Imperial China $\{$ Michael G. Chang $\}$

Bush, Untying the Knot: Making Peace in the Taiwan Strait \{Steven M. Goldstein\}

CAI (ed.), Chinese Aesthetics: The Ordering of Literature, the Arts, and the Universe in the Six Dynasties \{RoBert Ashmore\}

Chang, Literary Culture in Taiwan: Martial Law to Market Law \{Thomas Mor AN\}

CHIANG, Collecting the Self: Body and Identity in Strange Tale Collections of Late Imperial China $\{$ SARAh M. Allen $\}$

CHUng, Drawing Boundaries: Architectural Images in Qing China \{CARY Y. LIU\}

Crossley, Siu, and Sutton (eds.), Empire at the Margins: Culture, Ethnicity, and

Frontier in Early Modern China \{DAvid G. ATWILL

Csikszentmihalyi, Material Virtue: Ethics and the Body in Early China \{Roel STERCKX

Dubois, The Sacred Village: Social Change and Religious Life in Rural North China

\{RICHARD SHEK\}

ECONOmy, The River Runs Black: The Environmental Challenge to China's Future KelLy

Sims GALLAGHER\} 
Elman, On Their Own Terms. Science in China, 1550-1900 \{Catherine Jami\}

Goldman, From Comrade to Citizen: The Struggle for Political Rights in China $\{$ CHeng CHEN

Guo, Ritual Opera and Mercantile Lineage: The Confucian Transformation of Popular Culture in Late Imperial Huizhou \{BRIAN R. DOTT\}

Hamm, Paper Swordsmen: Jin Yong and the Modern Chinese Martial Arts Novel \{DenISE GIMPEL

HAR RISON, The Man Awakened from Dreams: One Man's Life in a North China Village $\{\mathrm{R}$. KeITH SCHOPPA

Hawes, The Social Circulation of Poetry in the Mid-Northern Song: Emotional Energy and Literati Self-Cultivation \{MeOw Hu GOH

Hevia, English Lessons: The Pedagogy of Imperialism in Nineteenth-Century China $\{\mathrm{J} . Y$. WONG

Hon, The Yijing and Chinese Politics: Classical Commentary and Literati Activism in the Northern Song Period, 960-1127 \{Colin S. C. HAw ES\}

Hsiung, A Tender Voyage: Children and Childhood in Late Imperial China \{KeITH N. KNAPP

Huters, Bringing the World Home: Appropriating the West in Late Qing and Early Republican China $\{$ Kirk A. Denton $\}$

Kong, Consuming Literature: Best Sellers and the Commercialization of Literary Production in Contemporary China \{CHR ISTOPHeR A. ReED\}

LAING, Selling Happiness: Calendar Posters and Visual Culture in Early Twentieth-Century Shanghai \{FrANCESCA DAL LAGO\}

Lu And Yeh (eds.), Chinese-Language Film: Historiography, Poetics, Politics \{Yiman W ANG

Lu, Street Criers: A Cultural History of Chinese Beggars \{ANDERs HANsson\}

Lupke (ed.), The Magnitude of Ming: Command, Allotment, and Fate in Chinese Culture \{JEFFREY L. RICHEY\}

Manion, Corruption by Design: Building Clean Government in Mainland China and Hong Kong \{BRUCE Dickson\}

MARMÉ, Suzhou: Where the Goods of All the Provinces Converge \{Hugh Clark

MoOre, Rituals of Recruitment in Tang China: Reading an Annual Programme in the Collected Statements by Wang Dingbao (870-940) \{Dennis Grafflin\}

Selover, Hsieh Liang-tso and the Analects of Confucius: Humane Learning as a Religious Quest \{Deborah Sommer\}

Strickmann (ed. Faure), Chinese Poetry and Prophecy: The Written Oracle in East Asia \{GIL RAZ\}

Sutter, China's Rise in Asia: Promises and Perils \{Hongying Wang\}

TER HAAR, Telling Stories: Witchcraft and Scapegoating in Chinese History \{XIAOFEI KANG\}

Theiss, Disgraceful Matters: The Politics of Chastity in Eighteenth-Century China (PAUL S. ROPP

W ANG, Illuminations from the Past: Trauma, Memory, and History in Modern China $\{$ XIAOBIN YANG

Wong, Chinese Steles: Pre-Buddhist and Buddhist Use of a Symbolic Form \{Bonnie CHENG 
Inner Asia

Atwood, Encyclopedia of Mongolia and the Mongol Empire \{Peter Jackson\}

BellezZA, Spirit-mediums, Sacred Mountains and Related Bon Textual Traditions in Upper

Tibet: Calling Down the Gods \{BRyan J. Cuevas\}

Bunker, WAtt, and Sun, Nomadic Art of the East Eurasian Steppe \{Francis Allard\}

Drompr, Tang China and the Collapse of the Uighur Empire. A Documentary History

\{Peter B. Golden\}

Edgar, Tribal Nation: The Making of Soviet Turkmenistan \{W ILliam FIERMAN\}

ERDAL, A Grammar of Old Turkic \{NATHAN LIGHT\}

Fischer, State Growth and Social Exclusion in Tibet: Challenges of Recent Economic Growth \{EMILY T. YEH

Goldstein, Sher ap, and Siebenschun, A Tibetan Revolutionary: The Political Life and Times of Bapa Phüntso Wangye \{RON SCHWARZ\}

Heylen, Chronique du Toumet-Ordos: Looking through the Lens of Joseph van Oost, Missionary in Inner Mongolia (1915-1921) \{JoHAN ElversKog\}

KARA, Books of the Mongolian Nomads: More than Eight Centuries of Writing Mongolian \{Peter A. Michalove

Komaroff and Carboni, The Legacy of Genghis Khan: Courtly Art and Culture in

Western Asia, 1256-1353 \{CHRISTIANE Gruber\}

Newby, The Empire and the Khanate: A Political History of Qing Relations with Khoqand c. 1760-1860 \{SCOTT C. LEVI\}

Pearlman, Tibetan Sacred Dance: A Journey into the Religious and Folk Traditions \{IsAbelle Henrion-Dourcy\}

Perry, A Tajik Persian Reference Grammar \{PAul Losensky\}

Powers, History as Propaganda: Tibetan Exiles versus the People's Republic of China \{Carole MCGranahan\}

Russell-Smith, Uygur Patronage in Dunbuang: Regional Art Centres on the Northern Silk Road in the Tenth and Eleventh Centuries \{MICHAel C. BROSE\}

Schaeffer, Himalayan Hermitess: The Life of a Tibetan Buddhist Nun \{SARAH H. JАCOBY $\}$

TAveirne, Han-Mongol Encounters and Missionary Endeavors: A History of Scheut in Ordos (Hetao), 1874-1911 \{Johan Elverskog\}

Tighe, Constructing Suiyuan: The Politics of Northwestern Territory and Development in Early

Twentieth-Century China \{URADYN E. BULAG

\section{Japan}

AMYx, Japan's Financial Crisis: Institutional Rigidity and Reluctant Change \{COSTAS LAPAVITSAS\}

Aoy agi, Islands of Eight Million Smiles: Idol Performance and Symbolic Production in Contemporary Japan $\{\mathrm{YU}-\mathrm{FEN} \mathrm{KO}\}$

Auslin, Negotiating with Imperialism: The Unequal Treaties and the Culture of Japanese Diplomacy \{Alexis DudDen\}

ClanCey, Earthquake Nation: The Cultural Politics of Japanese Seismicity, 1868-1930

$\{$ DON CHOI $\}$ 
Conant (ed.), Challenging Past and Present: The Metamorphosis of Nineteenth-Century Japanese Art \{Victoria Weston\}

COVELL, Japanese Temple Buddhism: Worldliness in a Religion of Renunciation UJUDITH SNODGRASS

Cox, The Zen Arts: An Anthropological Study of the Culture of Aesthetic Form in Japan UJoE PARKER

DodD, Writing Home: Representations of the Native Place in Modern Japanese Literature $\{$ ANGELA YiU\}

Dudden, Japan's Colonization of Korea: Discourse and Power \{NAM-LIN HuR

Fowler, Murōji: Rearranging Art and History at a Japanese Buddhist Temple \{CHRISTINE M.E. Guth

Hir at a, Discourses of Seduction-History, Evil, Desire, and Modern Japanese Literature \{JOSEPH MURPHY\}

Kaminishi, Explaining Pictures: Buddhist Propaganda and Etoki Storytelling in Japan

\{BArbara Ambros\}

KAW ANO, Ritual Practice in Modern Japan: Ordering place, people and action $\{\mathrm{D} . \mathrm{P}$. MARTINEZ\}

McLelland, Queer Japan from the Pacific War to the Internet Age \{Jose Ph HaW Kins\}

MCNAlly, Proving the Way: Conflict and Practice in the History of Japanese Nativism \{Peter Flueckiger\}

McRoy, Japanese Horror Cinema \{SUSAN NAPIER\}

Murphy, Metaphorical Circuit: Negotiations Between Literature and Science in 20th Century

Japan \{Hiromi MiZunO\}

Nakamur a, Practical Pursuits: Takano Chöei, Takahashi Keisaku, and Western Medicine in Nineteenth-Century Japan \{TER RENCE JACKSON\}

Olsen, The Chrysanthemum and the Song; Music, Memory, and Identity in the South American Japanese Diaspora \{CHRISTINE R. YANO\}

Ravina, The Last Samurai: The Life and Battles of Saigo Takamori \{Gregor y SMITs\}

Shimazono, From Salvation to Spirituality: Popular Religious Movements in Modern Japan \{HELEN HARDACRE\}

TOBIn (ed.), Pikachu's Global Adventure: The Rise and Fall of Pokémon \{IAN CONDRY\}

TOMIDA, Hiratsuka Raichō and Early Japanese Feminism \{JAN B A RDSLEY\}

Weston, Japanese Painting and National Identity: Okakura Tenshin and His Circle \{SARAH TEAsLey\}

Korea

KIM, Hidden Treasures: Lives of First-Generation Korean Women in Japan (W AYNE PATTERSON\}

Moon, Militarized Modernity and Gendered Citizenship in South Korea \{SHeILA MiYoshi JAGER \}

SHIN and HwAng (eds.), Contentious Kwangju: The May 18 Uprising in Korea's Past and Present $\{$ KIRK W. LARSEN $\}$

Smith, Hungry for Peace: International Security, Humanitarian Assistance, and Social Change in North Korea \{C. Kenneth Quinones\}

YI, Korean Landscape Painting: Continuity and Innovation Through the Ages (MARSHA

WEIDNER

South Asia

AgGaR w Al, Beyond Lines of Control: Performance and Politics on the Disputed Borders of Ladakh, India \{Jim FISHER 
AGRA W AL, Environmentality, Technologies of Government and the Making of Subjects

\{VINITA DAMODARAN\}

Alam, The Languages of Political Islam: India 1200-1800 \{Syed AKBAR Hyder\}

B ABB, Alchemies of Violence: Myths of Identity and the Life of Trade in Western India

\{ABIGAIL McGowan\}

BARUAH, Durable Disorder: Understanding the Politics of Northeast India \{YASMIN SAIKIA

Beckerlegge, The Ramakrishna Mission: The Making of a Modern Hindu Movement \{CARl Olson\}

Bhatia, Acts of Authority/Acts of Resistance: Theater and Politics in Colonial and Postcolonial India \{MAGGIE RONKIN\}

Bose (ed.), The Rāmāyana Revisited \{AJAy RAO\}

BRAss, The Production of Hindu-Muslim Violence in Contemporary India $\{\mathrm{KANCHAN}$

CHANDRA

CAtlin-Jair AZBhoy and Alpers, Sidis and Scholars: Essays on African Indians

\{FRANK J. KOROM

840

Copland, State, Community and Neighbourbood in Princely North India, c. 1900-1950

\{PAUL R. BRASS

640

DeCaroli, Haunting the Buddha: Indian Popular Religions and the Formation of Buddhism

\{JASON NEELIS\}

Ellinwood, Between Two Worlds: a Rajput Officer in the Indian Army: 1905-21

\{FRANCES TAFT $\}$

Ernst and Law rence, Sufi Martyrs of Love: The Chishti Order in South Asia and Beyond \{Sajida Sultana Alvi\}

GORSTHOEFL and HUMES (eds.), Gurus in America \{MICHAEL J. GRESSETT\} PATEL $\}$

Gopinath, Impossible Desires: Queer Diasporas and South Asian Popular Cultures \{LAWRENCE COHEN\}

Grewal, Transnational America: Feminisms, Diasporas, Neoliberalisms \{Lavina SHANKAR

Gulati and Bagchi, A Space of Her Own: Personal Narratives of Twelve Women \{SylviA VATUK\}

Hansen and Lelyveld (eds.), A Wilderness of Possibilities: Urdu Studies in Transnational

Perspective $\{$ AMY BARD

Hardgrove, Community and Public Culture: The Marwaris in Calcutta, c. 1897-1997

\{SWAPNA BANERJEE\}

Ismail, Abiding by Sri Lanka: On Peace, Place and Postcoloniality \{John D. Rogers\}

Jaffrelot, Dr. Ambedkar and Untouchability: Analysing and Fighting Caste \{GAIL OMVEDT

Joshi, Fractured Modernity: Making of A Middle Class In Colonial North India \{ROCHONA MAJUMDAR

Liechty, Suitably Modern: Making Middle-Class Culture in a New Consumer Society \{SARA SHNEIDERMAN\}

Luczanits, Buddhist Sculpture in Clay: Early Western Himalayan Art, Late 10th to Early 13th Centuries \{Katherine Anne Paul

Malik, Nectar Gaze and Poison Breath: An Analysis and Translation of the Rajasthani Oral Narrative of Devnarayan \{ANN GRODZINS GOLD\}

Masilamani-Meyer, Guardians of Tamilnadu: Folk Deities, Folk Religion, Hindu Themes \{Diane P. Mines\} 
McDaniel, Offering Flowers, Feeding Skulls: Popular Goddess Worship in West Bengal

\{Cynthia Ann Humes\}

446

Mohanty, Explorations in Philosophy: Indian Philosophy \{CARL Olson\}

435

NAYAR, The Sikh Diaspora in Vancouver: Three Generations amid Tradition, Modernity, and Multiculturalism \{Verne A. Dusenbery

Olivelle, Manu's Code of Law: A Critical Edition and Translation of the MānavaDharmaśāstra \{MIKAEL AKTOR

Pechilis (ed.), The Graceful Guru: Hindu Female Gurus in India and the United States \{Constantina Rhodes Bailly

PINney, Photos of the Gods: The Printed Image and Political Struggle in India \{RICHARD H. DAvis\}

Rinehart (ed.), Contemporary Hinduism: Ritual, Culture, and Practice \{Tr ACEY PinTCHMAN

Schwartz, Rasa: Performing the Divine in India \{Martha Ann Selby\}

Sharma, Modern Hindu Thought: The Essential Texts \{Carl Olson\}

Stewart (trans.), Fabulous Females and Peerless Pìrs: Tales of Mad Adventure in Old Bengal \{Glen Alexander Hayes\}

Suvorova, Muslim Saints of South Asia: The Eleventh to Fifteenth Centuries \{KAREN G. RUFFLE

Thapar, Somanatha: The Many Voices of a History \{Frank F. Conlon\}

Thekaekara, Endless Filth: The Saga of the Bhangis \{Henry Schwarz\}

Thirumali, Against Dora and Nizam: People's Movement in Telangana, 1939-1948

\{Peter L. SChmitthenner\}

VARShNey, Ethnic Conflict and Civic Life: Hindus and Muslims in India \{MANISH KUMAR THAKUR

VON HINÜBER, Die Palola Sahis: Ibre Steininschriften, Inschriften auf Bronzen, Handschriftenkolophone und Schutzzauber, Materialien zur Geschichte von Gilgit und Chilas. Antiquities of Northern Pakistan: Reports and Studies,Vol. 5 \{ADAM NAYYAR\}

W Adley, Raja Nal and the Goddess: The North Indian Epic, Dhola, in Performance \{William S. Sax $\}$

W Ater house (ed.), The Origins of Himalayan Studies: Brian Houghton Hodgson in Nepal and Darjeeling, 1820-1858 \{ArJun GuneratNe

Wolf, The Black Cow's Footprint: Time, Space and Music in the Lives of the Kotas of South India \{Isabelle Clark-DeCes\}

Southeast Asia

Callahan, Making Enemies: War and State Building in Burma \{James F. GuYOT\}

Gibson, And the Sun Pursued the Moon: Symbolic Knowledge and Traditional Authority among the Makassar \{Susan Rodgers\}

Giebel, Imagined Ancestries of Vietnamese Communism: Ton Duc Thang and the Politics of History and Memory \{David HunT\}

Gomes, Looking for Money: Capitalism and Modernity in an Orang Asli Village (PATRICIA SLOANE-WHITE

Houseman, Researching Indonesia: A Guide To Political Analysis \{Robert W. Hefner\} JanOwski, The Forest, Source of Life: The Kelabit of Sarawak \{Reed L. W Adley Kermel-Torres (ed.), Atlas of Thailand: Spatial Structures and Development \{James A. HAFNER\}

McCargo and Pathmanand, The Thaksinasation of Thailand \{DAniel H. Unger\} 
Nilsson Hoadery, Indonesian Literature vs. New Order Orthodoxy: The Aftermath of 1965-1966 \{Michael Bodden\}

Phongpaichit and BAKer, Thaksin: The Business of Politics in Thailand (DANiel H. UNGER \}

SAlemink, The Ethnography of Vietnam's Central Highlands: A Historical Contextualization, 1850-1900 \{CHRISTINA Firpo\}

SÁnchez Gómez, Un imperio en la vitrina: El colonialismo español en el Pacífico y la Exposición de Filipinas de 1887 \{Alda BlanCO\}

Selth, Burma's Armed Forces: Power Without Glory \{James F. GuYOT\}

Shirley, Guided by God: The Legacy of the Catholic Church in Philippine Politics

\{Kathleen Nadeau\}

VAN DER GRIJP, Identity and Development: Tongan Culture, Agriculture, and the Perenniality of the Gift \{Christian C. Lentz\}

WeAtherbee, International Relations in Southeast Asia: The Struggle for Autonomy \{Clark D. Neher $\}$ 


\section{Contributors}

Aktor, Mikael, 850

Algoso, Teresa A., 555

Allard, Francis, 410

Allen, Sarah M., 157

Alvi, Sajida Sultana, 431

Ambros, Barbara, 826

Andaya, Barbara, 669

Ashiwa, Yoshiko, 337

Ashmore, Robert, 154

Atwill, David G., 604

Bailly, Constantina Rhodes, 212

Banerjee, Swapna, 643

Bard, Amy, 847

Bardsley, Jan, 632

Barnett, Robert, 417

Blanco, Alda, 231

Bodden, Michael H., 660

Brass, Paul R., 640

Brose, Michael C., 621

Brown, Rebecca M., 91

Bulag, Uradyn E., 3, 188

Callahan, William A., 394

Chandra, Kanchan, 207

Chang, Michael G., 603

Cheng Chen, 802

Cheng, Bonnie, 180

Choi, Don, 823

Clark, Hugh, 172

Clark-Deces, Isabelle, 454

Cohen, Lawrence, 844

Condry, Ian, 200

Conlon, Frank F., 852

Crossley, Pamela, 408

Cuevas, Bryan J., 814

Culp, Robert, 529

Dal Lago, Francesca, 407

Damodaran, Vinita, 837

Davis, Richard H., 648

de Pee, Christian, 691

Denton, Kirk A., 166

Dickson, Bruce, 808

Dittmer, Lowell, 149

Dott, Brian R., 160

Dudden, Alexis, 191

Dusenbery, Verne A., 211

Elverskog, Johan, 820, 821

Fierman, William, 816

Firpo, Christina, 229

Fisher, Jim, 835
Flueckiger, Peter, 629

Foster, Michael Dylan, 251

Freeman, Carla P., 396

Gallagher, Kelly Sims, 403

Giersch, C. Patterson, 797

Gimpel, Denise, 162

Glosser, Susan, 148

Goh, Meow Hui, 803

Gold, Ann Grodzins, 444

Golden, Peter, 411

Goldstein, Steven M., 799

Goossaert, Vincent, 307

Grafflin, Dennis, 174

Gressett, Michael J., 842

Gruber, Christiane, 817

Guneratne, Arjun, 437

Guth, Christine M.E., 192

Guyot, James F., 222

Hafner, James A., 656

Hansson, Anders, 807

Hardacre, Helen, 199

Hawes, Colin S. C., 608

Hawkins, Joseph, 828

Hayes, Glen Alexander, 216

Hefner, Robert W., 654

Henrion-Dourcy, Isabelle, 185

Hongying Wang, 612

Humes, Cynthia Ann, 446

Hunt, David, 225

Hur, Nam-lin, 424

Hutt, Michael, 361

Hyder, Syed Akbar, 204

Jackson, Peter, 613

Jackson, Terrence, 830

Jacoby, Sarah H., 819

Jager, Sheila Miyoshi, 425

Jami, Catherine, 405

Keirstead, Thomas, 601

Klima, Alan, 393

Knapp, Keith N., 165

Korom, Frank J., 840

La Croix, Sumner J., 145

Lamarre, Thomas, 794

Lapavitsas, Costas, 189

Larsen, Kirk W., 635

Lentz, Christian C., 227

Levi, Scott C., 618

Li Tana, 152

Light, Nathan, 413

Lincicome, Mark, 151 
Liu, Cary Y., 400

Lorenzen, David N., 115

Losensky, Paul 183, 419

Majumdar, Rochona, 440

Mark, Ethan, 461

Martinez, D. P., 194

May, Timothy, 182

McGowan, Abigail, 205

McGranahan, Carole, 620

Michalove, Peter A., 617

Mines, Diane P., 646

Mizuno, Hiromi, 630

Moore, Gregory J., 812

Moran, Tom, 155

Mosse, David, 61

Murphy, Joseph, 626

Nadeau, Kathleen, 662

Napier, Susan, 195

Nayyar, Adam, 453

Neelis, Jason, 209

Neher, Clark D., 457

Olson, Carl, 428, 435, 449

Omvedt, Gail, 438

Parker, Joe, 420

Patel, Alka, 641

Patterson, Wayne, 202

Paul, Katherine Anne, 442

Ping Shao, 713

Pintchman, Tracey, 214

Quinones, C. Kenneth, 831

Rao, Ajay, 838

Raz, Gil, 175

Reed, Christopher A., 609

Richey, Jeffrey L., 170

Rodgers, Susan, 651, 855

Rogers, John D., 849

Ronkin, Maggie, 638

Ropp, Paul S., 177

Roy, Srirupa, 495

Ruffle, Karen G., 450
Saikia, Yasmin, 33, 636

Sax, William S., 853

Schmitthenner, Peter L., 219

Schoppa, R. Keith, 163

Schwartz, Ron, 615

Schwarz, Henry, 217

Selby, Martha Ann, 447

Shankar, Lavina, 433

Shek, Richard, 159

Shneiderman, Sara, 645

Simei Qing, 793

Sloane-White, Patricia, 653

Smits, Gregory, 198

Snodgrass, Judith, 624

Sommer, Deborah, 611

Sterckx, Roel, 606

Suzuki, Michiko, 575

Taft, Frances, 429

Teasley, Sarah, 633

Thakur, Manish Kumar, 221

Unger, Daniel H., 658

Vatuk, Sylvia, 845

Wadley, Reed L., 456

Wank, David L., 337

Wei Hua, 741

Weidner, Marsha, 833

Weston, Victoria, 825

Widmer, Ellen, 763

Wong, J. Y., 805

Xiangming Chen, 398

Xiaobin Yang, 179

Xiaofei Kang, 811

Yano, Christine R., 197

Yeh, Emily T., 415

Yiman Wang, 169

Yiu, Angela, 422

Yoda, Tomiko, 277

Yu-Fen Ko, 623 


\section{IN This Issue}

Presidential Address

Oceans Unbounded: Transversing Asia across "Area Studies"

BARBARA WATSON ANDAYA

Textual Excursions in China

Till Death Do Us Unite: Texts, Tombs, and the

Cultural History of Weddings in Middle-Period

China (Eighth through Fourteenth Century)

Christian de Pee

Huineng, Subhūti, and Monkey's Religion in

Xiyou $j i$

PING SHAO

How Dangerous Can the Peony Be? Textual Space,

Caizi Mudan ting, and Naturalizing the Erotic

WeI HuA

Foreign Travel through a Woman's Eyes: Shan Shili’s

Guimao luxing $j i$ in Local and Global Perspective

ELLEN WIDMER

\section{The Journal of Asian Studies}

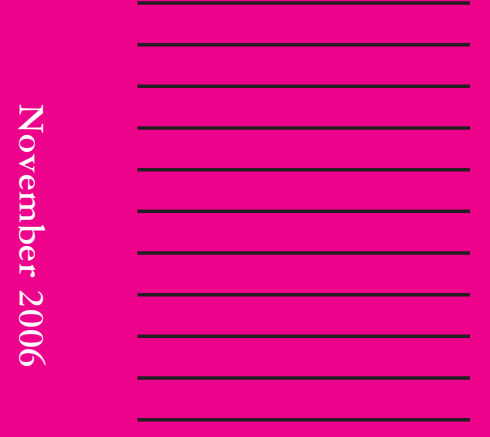

NOVEMBER 2006

PUBLISHED BY

THE ASSOCIATION

FOR ASIAN STUDIES, INC. 